\section{Functional performance of the elderly in instrumental activities of daily living: an analysis in the municipality of São Paulo, Brazil}

\author{
Desempenho funcional de idosos nas atividades \\ instrumentais da vida diária: uma análise no \\ Município de São Paulo, Brasil
}

\author{
${ }^{1}$ Faculdade de Medicina de \\ Ribeirão Preto, Universidade \\ de São Paulo, Ribeirão Preto, \\ Brasil. \\ 2 Faculdade de Saúde \\ Pública, Universidade de \\ São Paulo, São Paulo, Brasil. \\ 3 Escola de Enfermagem \\ Universidade de São Paulo, \\ São Paulo, Brasil. \\ Correspondence \\ J. L. F. Santos \\ Departamento de Medicina \\ Social, Faculdade de \\ Medicina de Ribeirão Preto, \\ Universidade de São Paulo. \\ Av. Bandeirantes 3900, \\ Ribeirão Preto, $S P$ \\ 14049-900, Brasil. \\ jalifesa@usp.br
}

\begin{abstract}
The changes that occur during aging are accompanied by limitations in functional performance that impair elderly people's social participation and consequently harm their quality of life. In the SABE Study (São Paulo, Brazil), the results indicated relationships between life expectancy without disabilities and demographic and social variables. This article sought to evaluate these and other variables together as explanatory factors for the presence or absence of difficulties in instrumental activities of daily living (IADL), directly related to the possibility of more efficient community participation. Five of the eight questions relating to IADL that were applied to the sample of 2,143 elderly individuals in the municipality of São Paulo in 2000 were considered. Odds ratios were calculated using logistic regression. All the socio-demographic variables analyzed (age, income, ethnicity, schooling, and gender) were significant, with the exception of "sufficient money". All the variables in the "health" group (one or two or more diseases reported, and depression) were also significant. The two other variables that entered the model were physical activity and alcohol consumption.
\end{abstract}

Activities of Daily Living; Quality of Life; Frail Elderly; Aging
Jair Licio Ferreira Santos 1

Maria Lucia Lebrão 2

Yeda Aparecida Oliveira Duarte ${ }^{3}$

Fernão Dias de Lima 2

\section{Introduction}

The demographic transition in its different phases around the world, together with the epidemiological transition, resulted in the main demographic phenomenon in the late $20^{\text {th }}$ century, namely the unparalleled growth of the elderly population and important changes in aging indicators 1 . Meanwhile, it has become necessary to reorganize healthcare and incorporate other professionals into health teams in order to deal with the main challenge of the $21^{\text {st }}$ century, according to the World Health Organization (WHO), i.e., the prevalence of chronic non-communicable diseases among population segments at previously unimaginable rates and proportions 2 .

The WHO document highlighting the worldwide importance of chronic diseases lists the critical elements, including increased prevalence and incidence, lack of health systems' preparedness to respond to the growing demand, and the serious economic and social consequences ${ }^{2}$. For Brazil and Latin America in general, these conditions are even more acute due to the features of the social context and the demographic transition itself 3 .

In association with the changes resulting from aging and the prevalence of chronic diseases, functional alterations resulting in loss of ability to perform instrumental activities of daily living (IADL) are important determinants of loss of independence and autonomy among elderly 
persons, worse quality of life, and increased demand for specialized care 4 .

\section{The SABE Study}

Coordinated by the Pan-American Health Organization (PAHO), the SABE Study is a multicenter study conducted in seven countries in Latin America and the Caribbean. The project aimed to investigate the living conditions, health, and well-being of elders in the region. In Brazil, the sample included 2,143 subjects over 60 years of age who were living in the municipality of São Paulo in the year 2000, selected through multiple-stage sampling 1,5 .

\section{Methodology}

\section{Sample}

The current article is part of the SABE Study. The sample included 2,143 persons over 60 years of age, interviewed for the study. After the exclusions mentioned below, 1,479 cases remained for the analysis, of which 1,034 did not present any difficulties in IADL (69.9\%) and 445 presented one or more difficulties $(30.1 \%)$.

\section{Dependent variable: difficulty}

In this study, individuals were defined as presenting difficulty if an affirmative response was given to at least one of the questions referring to difficulties in performing IADL, shown in Table 1. This variable is considered the "response" in the analysis that follows. Of the eight questions used to evaluate these difficulties, the ones relating to preparation of hot meals (D18a) and performing light domestic tasks (D23a) and heavy domestic tasks (D24a) were not considered because they would have introduced a potentially strong cultural bias, and thus corresponded less directly to the socio-demographic and health variables targeted by the present study. The option "does not usually do this" was also defined as "no response", because it was more related to personal habits than to performance difficulties as such. Likewise, cases of "does not know" or "no response" were eliminated. Thus, each of the questions on IADL had only two responses: no (the individual experienced no difficulty) or yes (the individual experienced the difficulty), and the dependent variable also had two categories: 0 - the individual had no difficulties in relation to any of the five questions; or 1 - the individual presented one or more difficulties.
Independent variables

\section{- Socio-demographic group}

Health inequalities can be identified by various measurements specified for certain social or demographic characteristics, including age, gender, ethnicity, income, and schooling 6 . All these variables were included in this study and were assumed to be independent for the analysis. For the elderly individual's personal income, two types of information were used: position within the sample's income distribution and a variable referred to here as "money", which was the answer to the question "Do you consider your money sufficient for your needs?”.

\section{- Conditions associated with current life profile}

Santos 7 studied disability-free survival and also considered the socio-demographic variables of "marital status" and "presence of companion" as differentials for life expectancy. The current study also considered these as possible factors associated with difficulties in IADL. The variables physical activity and mental activity were added to these.

\section{- Conditions associated previous life profile}

As indicators of the earlier conditions in the elderly person's life, the following variables were analyzed: children (number of live-born children) and work (classifying the individual's employment status as employer, self-employed, or other).

\section{- Presence of risk factors}

Alcohol and tobacco consumption, traditional risk factors for elderly individuals' health and living conditions, were included in this category. No alcohol consumption was positively correlated with decline in functional status in several studies 8 . Thus, an indicator of low consumption - no alcohol during the last 3 months - was adopted in the analysis.

\section{- Health-related conditions}

The variables depression (presence or absence) and reported number of diseases were included in this group. Self-reported diseases were: hypertension, diabetes, cancer, lung disease, heart disease, arthritis/arthrosis, and stroke. For depression, absence (no) was defined as less than or equal to 6 on the Geriatric Depression Scale 9. 
Questions on instrumental activities of daily living (IADL) in the SABE Study questionnaire. São Paulo, Brazil.

\begin{tabular}{ll}
\hline Number & \\
\hline D.19a & Do you have difficulty managing your own money? \\
D.20a & Do you have difficulty going out alone, like going to the doctor, to church, etc.? \\
D.21a & Do you have difficulty shopping for food? \\
D.22a & Do you have difficulty using the telephone? \\
D.25a & Do you have difficulty taking your medicines? \\
\hline
\end{tabular}

Source: available at http://hygeia.fsp.usp.br/sabe/ (accessed on 05/Mar/2007).

Values of more than 6, corresponding to the mild, moderate, and severe categories, were grouped into a single class representing presence of depression (yes). The reported number of diseases was transformed into three dummy variables for ease of interpretation. The basic category grouped the categories of $0=$ no reported disease and $1=$ one or more diseases. Variables included in the analysis were disease 1 (exactly one disease reported) and disease 2 (two or more diseases reported).

\section{- Analytical model}

Since we intended to simultaneously evaluate the effects of the independent variable on the response variable and to rank the possible influences, we adopted multivariate logistic regression analysis, for which a stepwise regression model was chosen 10 in which all the available variables started as part of the process and were removed when their explanatory power no longer reached the specified 5\% significance level. Each observation was weighted accordingly to compensate for the effects of delineation 5. Comparison of the effect on the response variable used odds ratios, with confidence intervals estimated at the same significance level. For more adequate interpretation of the regression results, all variables were dichotomized and grouped into two classes: 0 as the reference class and 1 as the contrast. Information on the classes "does not know" and "no response" and missing values were ignored. Table 2 shows the variables and definitions for the reference and contrast categories.

The study was approved by the Research Ethics Committee of the Faculdade de Saúde Pública, Universidade de São Paulo [School of Public Health, University of São Paulo] (letter no. 67/99), and by the Comissão Nacional de Ética em Pesquisa [CONEP; Brazilian National Research Ethics Committee], report no. 315/99.

\section{Results}

Table 3 shows the results from expanding the sample to compare each independent variable with the response variable in terms of relative frequencies. For the whole sample, $30.1 \%$ of respondents experienced one or more difficulties in the five IADL. When responses were analyzed according to categories of independent variables, the possible unadjusted associations could be evaluated, the most important of which related to age: $48.9 \%$ of individuals 75 years and older had difficulties, compared to $15.3 \%$ of those aged 60 to 74 . Other variables with frequencies greater than $30 \%$ for difficulties were: two or more reported diseases (31.3\% versus $13.2 \%$ ), depression $(34.4 \%$ versus $12.3 \%)$, income $(35.2 \%$ versus $14 \%$ ), and schooling (32.1\% versus $13.2 \%)$. Alcohol consumption was inversely related, thus appearing as a possible "protective factor": $8.4 \%$ versus $28.3 \%$. In fact, the hypothesis was that this result (still requiring confirmation in the multivariate analysis) merely represented the possibility that individuals with no difficulties in IADL were able to consume alcohol.

By applying the stepwise logistic regression model, seven independent variables were removed, with probability of occurrence ranging from 0.96 (employment status) to 0.16 (sufficient money). The other variables, all with significant odds ratios, formed the final model presented in Table 4.

All the significant odds ratios were of considerable magnitude. The most important, two or more reported diseases, showed five times the odds of difficulties in IADL. In decreasing order of importance, the other factors were age ( $>75$ years, $\mathrm{OR}=3.4$ ), lack of physical activity, alcohol consumption (which should be interpreted as discussed above, in the bivariate analysis), one reported disease, depression, income, ethnicity, schooling, and finally gender. 
Names, definitions, and categories of variables used in the analytical model.

\begin{tabular}{|c|c|c|c|}
\hline & Definitions & Reference & Contrast \\
\hline \multicolumn{4}{|l|}{ Independent variables } \\
\hline \multicolumn{4}{|l|}{ Socio-demographic } \\
\hline Age & Age in years & $60-74$ & $\geq 75$ \\
\hline Gender & Gender of interviewee & Male & Female \\
\hline Schooling & Years of study completed & $\geq 4$ years & $\leq 3$ years \\
\hline Income & Position in the distribution & $>2^{\text {nd }}$ quintile & $\leq 2^{\text {nd }}$ quintile \\
\hline Money & Considers available money sufficient & Yes & No \\
\hline Ethnicity & Self-reported race or color & White & Non-white \\
\hline \multicolumn{4}{|c|}{ Conditions connected with } \\
\hline \multicolumn{4}{|l|}{ earlier lifestyle } \\
\hline Children & Number of children & $\leq 2$ & $\geq 3$ \\
\hline Work & Employment status & Employer or self-employed & All others \\
\hline \multicolumn{4}{|c|}{ Conditions connected with } \\
\hline \multicolumn{4}{|c|}{ present lifestyle } \\
\hline Marriage & Marital status & Not married & Married \\
\hline Company & Presence of companion in the home & Living alone & Living accompanied \\
\hline Physical activity & Physical activity in previous year & Yes & No \\
\hline Mental activity & Manual or handicraft activity & Yes & No \\
\hline \multicolumn{4}{|c|}{ Presence of risk factors } \\
\hline Alcohol & $\begin{array}{c}\text { Had any alcoholic beverage in } \\
\text { previous } 3 \text { months }\end{array}$ & No & Yes \\
\hline Tobacco & Tobacco use & Never smoked & $\begin{array}{l}\text { Current or past } \\
\text { smoker }\end{array}$ \\
\hline \multicolumn{4}{|l|}{ Health conditions } \\
\hline Depression & Current mild, moderate, or severe depression & No & Yes \\
\hline Disease 1 & One disease reported & No & Yes \\
\hline Disease 2 & Two or more diseases reported & No & Yes \\
\hline \multicolumn{4}{|l|}{ Dependent variable } \\
\hline Difficulty & Difficulty performing $\geq 1$ of 5 IADL & No & Yes \\
\hline
\end{tabular}

\section{Discussion}

Previous studies 4,11,12 had already suggested the influence of age and gender on difficulties in IADL. Importantly, in the socio-demographic group, only the variable "sufficient money" failed to present a significant result, although the variable "income" did. This point suggests the need for further research: it appears that income, which may express more active living conditions in the past, has an effect on current IADL, since they include activities that are more connected to the community, while the availability of money, perhaps expressing more present-day conditions, affects the difficulties in basic activities of daily living, in which dependence generally requires the presence of a caregiver.

Some of these variables had already been associated with difficulties in the IADL that were identified. Thus, schooling was already mentioned in previous studies in relation to IADL 7 and also in other results obtained from the National Sample Household Survey (PNAD) data, which are therefore only indirectly comparable 13 . Other variables are new in studies of this type. They include ethnicity, indicating that "nonwhite" ethnicity is a protective factor that decreases the odds of difficulties in IADL by a factor of 0.57 .

The two variables used to attempt to capture some effect from the individuals' earlier lifestyles did not present significant odds ratios. Once again, in the study on IADL, the number of children was significant, with an odds ratio of 1.60. The idea in including these variables was to have some information on earlier lifestyles. Thus, fewer children might indicate a more "urban" and "modern" lifestyle, with more children reflecting 
Percentage distribution of difficulties in IADL - total for expanded sample and according to independent variables.

\begin{tabular}{|c|c|c|c|c|}
\hline \multirow[t]{2}{*}{ Groups } & \multirow[t]{2}{*}{ Variables } & \multirow[t]{2}{*}{ Categories } & \multicolumn{2}{|c|}{ Presence of difficulties } \\
\hline & & & No & Yes \\
\hline \multicolumn{5}{|c|}{ Socio-demographic } \\
\hline & Age (years) & $60-74$ & 84.7 & 15.3 \\
\hline & & $\geq 75$ & 51.1 & 48.9 \\
\hline & Gender & Male & 86.6 & 13.4 \\
\hline & & Female & 72.9 & 27.1 \\
\hline & Schooling (years) & $\geq 4$ & 86.8 & 13.2 \\
\hline & & $\leq 3$ & 67.9 & 32.1 \\
\hline & Income & $>2$ nd quintile & 86.0 & 14.0 \\
\hline & & $\leq 2$ nd quintile & 64.8 & 35.2 \\
\hline & Money & Yes & 85.4 & 14.6 \\
\hline & & No & 75.2 & 24.8 \\
\hline & Ethnicity & White & 78.3 & 21.7 \\
\hline & & Non-white & 78.8 & 21.2 \\
\hline \multicolumn{5}{|c|}{ Conditions connected with earlier lifestyle } \\
\hline & Number of children & $\leq 2$ & 81.3 & 18.7 \\
\hline & & $\geq 3$ & 76.3 & 24.7 \\
\hline & Work & Employer/Self-employed & 80.2 & 19.8 \\
\hline & & Other & 78.7 & 21.3 \\
\hline \multicolumn{5}{|c|}{ Conditions connected with present lifestyle } \\
\hline & Marriage & Not married & 70.8 & 29.2 \\
\hline & & Married & 84.0 & 16.0 \\
\hline & Company & Living alone & 75.5 & 24.5 \\
\hline & & Living accompanied & 78.9 & 21.1 \\
\hline & Physical activity & Yes & 93.3 & 6.7 \\
\hline & & No & 72.3 & 27.8 \\
\hline & Mental activity & Yes & 84.9 & 15.1 \\
\hline & & No & 75.4 & 24.6 \\
\hline \multicolumn{5}{|c|}{ Presence of risk factors } \\
\hline & Alcohol & No & 71.7 & 28.3 \\
\hline & & Yes & 91.6 & 8.4 \\
\hline & Tobacco & No & 76.5 & 23.5 \\
\hline & & Yes & 80.6 & 19.4 \\
\hline \multicolumn{5}{|l|}{ Health conditions } \\
\hline & Depression & No & 87.7 & 12.3 \\
\hline & & Yes & 65.6 & 34.4 \\
\hline & Disease 1: one disease & No & 75.4 & 24.6 \\
\hline & & Yes & 85.3 & 14.7 \\
\hline & Disease 2: 2 or more diseases & No & 86.8 & 13.2 \\
\hline & & Yes & 68.7 & 31.3 \\
\hline Total for sample & & & 69.9 & 30.1 \\
\hline
\end{tabular}

a more rural and traditional lifestyle. Meanwhile, employment status (employer or self-employed) could also express influences from general living conditions in the past.

Among the conditions associated with current life, only the variable "physical activity" showed significance. Thus, physically inactive in- dividuals showed 2.88 times the odds of presenting difficulties in IADL. Again, this result should be analyzed from the perspective of an association between factors, rather than as a cause-andeffect relationship. Individuals are more likely to have some physical activity if they do not have other problems connected with IADL. Mean- 
Results of stepwise logistic regression for the response variable of difficulties in IADL.

\begin{tabular}{|c|c|c|c|c|c|c|}
\hline \multirow[b]{2}{*}{ Variables } & \multicolumn{2}{|c|}{ Pseudo R2 = 0.2394} & \multicolumn{2}{|c|}{$\mathrm{p}($ Wald test $)<0.000$} & \multirow{2}{*}{\multicolumn{2}{|c|}{$\begin{array}{c}\mathrm{N}=1,037 \\
\text { Confidence interval }(95 \% \mathrm{Cl})\end{array}$}} \\
\hline & Reference & Contrast & Adjusted & $p$ & & \\
\hline$\geq 2$ diseases & No & Yes & 5.03 & 0.000 & 2.64 & 9.59 \\
\hline Age (years) & $60-74$ & $\geq 75$ & 3.40 & 0.000 & 2.29 & 5.05 \\
\hline Physical activity & $\begin{array}{l}\text { Exercised in } \\
\text { previous year }\end{array}$ & Did not exercise & 2.88 & 0.001 & 1.56 & 5.32 \\
\hline Alcohol consumption & No & Yes & 0.38 & 0.000 & 0.23 & 0.62 \\
\hline One disease reported & No & Yes & 2.45 & 0.012 & 1.22 & 4.93 \\
\hline Presence of depression & No & Yes & 2.20 & 0.002 & 1.33 & 3.64 \\
\hline Income & $>$ 2nd quintile & $\leq 2$ nd quintile & 2.08 & 0.001 & 1.35 & 3.21 \\
\hline Ethnicity & White & Non-white & 0.57 & 0.024 & 0.35 & 0.93 \\
\hline Schooling & $\geq 4$ years & $\leq 3$ years & 1.68 & 0.019 & 1.09 & 2.58 \\
\hline Gender & Male & Female & 1.67 & 0.025 & 1.07 & 2.61 \\
\hline
\end{tabular}

while, physical activity can improve the individual's general condition, thus decreasing the difficulties in daily activities.

Alcohol and tobacco consumption were included in the analysis, given their great potential as general risk factors for health. As with physical activity, alcohol consumption was shown to be a significant protective factor against difficulties in IADL. As already discussed, this result should also be interpreted as an association between absence of difficulties in IADL and being able to continue consuming some alcohol.

All the variables used as indicators of health conditions remained in the model. Reporting exactly one disease increased the odds of difficulties in IADL by 2.45 . Reporting two diseases multiplied this factor again by more than two, thus clearly demonstrating the impact of comorbidities on elderly people's quality of life. Likewise, depression more than doubled the odds of difficulties in IADL.

Models with interaction between age and each of the other variables were also tested, considering that increasing age permeates the changes that are specific to the elderly. All the models (except one) maintained exactly the same likelihood (logarithm of the pseudo-likelihood $=-339.3$ ), i.e., the interactions were not significant. In the model incorporating the interaction between "two or more reported diseases" and age, the pseudo R2 increased to 0.2434 and the logarithm of the pseudo-likelihood changed from -337.6 to -339.3. However, the likelihood ratio resulted in 3.4 , and when compared to the critical value for chi-squared (a degree of freedom of 3.84), the increase in R2 was not significant 14 .
A previous survey in the municipality of São Paulo also found significant odds ratios for different levels of schooling in relation to functional capacity (considered together). Again, the use of different categories and classes, plus different specifications in the regression model, may produce some differences. Other variables showed similar behavior to our results 15 .

Several of the results found here are consistent with other studies. Results from surveys of American populations, although with different definitions and focuses than those adopted in the SABE Study, indicated that disabilities increased with age, were greater among elderly women, and were less pronounced in individuals with higher income and more schooling 16 . With regard to ethnicity, the same authors found that blacks presented the same prevalence of disabilities as whites, but differing in degree: blacks had fewer minor disabilities (7.8\% versus $10.3 \%)$ but more severe disabilities (12.2\% versus $9.8 \%)$. Meanwhile, Asians had the lowest overall prevalence $(9.9 \%)$ of both the minor $(5 \%)$ and severe disabilities (4.9\%).

\section{Conclusions}

The results of this study are important for the health sector in general and for healthcare targeting the elderly in particular. Age, gender, income, schooling, and ethnicity were socio-demographic conditioning factors for the odds of difficulties in IADL. These have been mentioned by some authors as better indicators of quality of life than the presence of specific diseases 17 . 
However, the presence of two or more reported diseases was by far the most important variable for difficulties in IADL. Living with diseases and disabilities in activities of daily living is a burden for the elderly and for their companions, caregivers, and partners.

\section{Resumo}

As alterações que ocorrem no envelhecimento são acompanhadas por limitações no desempenho funcional que comprometem a participação social da pessoa idosa, conseqüentemente prejudicando sua qualidade de vida. No Estudo SABE (São Paulo, Brasil), os resultados apontaram relações entre a esperança de vida sem incapacidades e variáveis demográficas e sociais. Neste artigo buscou-se uma avaliação conjunta dessas e outras variáveis como explanadoras da presença ou não de dificuldades em atividades instrumentais da vida diária diretamente relacionadas com a possibilidade de uma participação comunitária mais eficiente. Foram consideradas cinco das oito questões relativas às atividades instrumentais da vida diária, aplicadas à amostra de 2.143 idosos do Município de São Paulo, em 2000. Razões de chance foram calculadas por regressão logística. Todas as variáveis sócio-demográficas analisadas (idade, renda, etnia, escolaridade e sexo) com exceção de "suficiência de dinheiro" foram significantes, bem como todas as variáveis do grupo "saúde" (uma, duas ou mais doenças referidas e depressão). As duas outras variáveis que entraram no modelo foram atividade física e consumo de álcool.

Atividades Cotidianas; Qualidade de Vida; Idoso Débil; Envelhecimento

\section{Contributors}

J. L. F. Santos was responsible for the statistical methodology and writing and organizing the text. M. L. Lebrão coordinated the project and managed the fieldwork, ranging from formulation of the questions in Portuguese to their refinement and adaptation to local conditions. Y. A. O. Duarte acted as a researcher in the project, in various capacities. She selected and critically reviewed the variables, especially those related to IADL and the respective disabilities. F. D. Lima served as the project analyst, and constructed, critically analyzed, refined, and maintained the database, which he adapted to the objectives and techniques used in the analysis.

\section{Acknowledgments}

The Conselho Nacional de Desenvolvimento Científico e Tecnológico [CNPq; Brazilian National Research Council] provided a research productivity scholarship for J. L. F. Santos. 


\section{References}

1. Palloni A, Peláez M. Histórico e natureza do estudo. In: Lebrão ML, Duarte YAO, organizadores. SABE - Saúde, Bem-Estar e Envelhecimento. O projeto SABE no Município de São Paulo: uma abordagem inicial. Brasília: Organização Pan-Americana da Saúde; 2003. p. 13-32.

2. Organização Mundial da Saúde. Cuidados inovadores para condições crônicas: componentes estruturais de ação: relatório mundial. Brasília: Organização Pan-Americana da Saúde; 2003.

3. Lebrão ML, Duarte YAO, organizadores. SABE - Saúde, Bem-Estar e Envelhecimento. O projeto SABE no Município de São Paulo: uma abordagem inicial. Brasília: Organização Pan-Americana da Saúde; 2003

4. Duarte YAO, Lebrão ML, Lima FD. The contribution of living arrangements in the provision of care for elderly persons with functional impairments in São Paulo, Brazil. Rev Panam Salud Pública 2005; 17:370-8.

5. Silva NN. Aspectos metodológicos: processo de amostragem. In: Lebrão ML, Duarte YAO, organizadores. SABE - Saúde, Bem-Estar e Envelhecimento. O projeto SABE no Município de São Paulo: uma abordagem inicial. Brasília: Organização PanAmericana da Saúde; 2003. p. 47-57.

6. Braveman P. Health disparities and health equity: concepts and measurement. Annu Rev Public Health 2006; 27:167-94.

7. Santos, JLF. Análise de sobrevida sem incapacidades. In: Lebrão ML, Duarte YAO, organizadores. SABE - Saúde, Bem-Estar e Envelhecimento. O projeto SABE no Município de São Paulo: uma abordagem inicial. Brasília: Organização PanAmericana da Saúde; 2003. p. 169-81.
8. Stuck AE, Walthert JM, Nikolaus T, Büla CJ, Hohmann C, Beck JC. Risk factors for functional status decline in community-living elderly people: a systematic literature review. Soc Sci Med 1999; 48: 445-69.

9. Paradela EMP, Lourenço RA, Veras RP. Validação da escala de depressão geriátrica em um ambulatório geral. Rev Saúde Pública 2005; 39:918-23.

10. Hamilton LC. Statistics with Stata. Toronto: Thomson Learning; 2003.

11. Njegovan V, Hing MM, Mitchell SL, Molnar FJ. The hierarchy of functional loss associated with cognitive decline in older persons. J Gerontol A Biol Sci Med Sci 2001; 56:M638-43.

12. Gill TM, Robison JT, Tinetti ME. Difficulty and dependency: two components of the disability continuum among community-living older persons. Ann Intern Med 1998; 128:96-101.

13. Parahyba MI, Veras R, Melzer D. Incapacidade funcional entre mulheres idosas no Brasil. Rev Saúde Pública 2005; 39:383-91.

14. Afif A, Clark VA, May S. Computer-aided multivariate analysis. $4^{\text {th }}$ Ed. Boca Raton: Chapman \& Hall/ CRC Press; 2004.

15. Rosa TEC, Benício MHD’A, Latorre MRDO, Ramos LR. Fatores determinantes da capacidade funcional entre idosos. Rev Saúde Pública 2003; 37:40-8.

16. Kraus E, Stoddard S, Gilmartin D. Chartbook on disability in the Unites States, 1996. An InfoUse report. Washington DC: National Institute on Disability and Rehabilitation Research; 1996.

17. Berkman CS, Gurland BJ. The relationship among income, other socioeconomic indicators, and functional level in older persons. J Aging Health 1998; 10:81-98.

Submitted on 26/Mar/2007

Final version resubmitted on 14/Aug/2007

Approved on 30/Aug/2007 